\title{
PENGARUH MEDIA PEMBELAJARAN DAN MOTIVASI BELAJAR TERHADAP PRESTASI BELAJAR PENCAPAIAN KOMPETENSI RESUSITASI BAYI BARU LAHIR
}

\author{
Umi Baroroh ${ }^{1}$ \\ Email: mid_umi@yahoo.co.id \\ ${ }^{1}$ Diploma III Kebidanan, Politeknik Harapan Bersama \\ Jalan Mataram No 9 Kota Tegal 52142 \\ Telp/Fax (0283) 352000
}

\begin{abstract}
Abstrak
Pengajar harus menggabungkan beberapa metode pembelajaran yang beragam, menarik dan menantang. Teknologi mempunyai dampak positif untuk memotivasi mahasiswa, teknologi juga mempunyai dampak positif untuk meningkatkan prestasi belajar mahasiswa. ${ }^{9}$

Jenis penelitian yang digunakan adalah kuantitatif eksperimendengan menggunakan pendekatan true eksperimen, populasinya adalah mahasiswa tingkat 2 Prodi Kebidanan Politeknik Harapan Bersama. Teknik analisis data menggunakan teknik anova 2 jalur. Hasil analisis menunjukan bahwa terdapat perbedaan pengaruh media pembelajaran 3 dimensi dan media pembelajaran VCD Interaktif terhadap prestasi belajar dengan $\mathrm{p}(0,016)<0.05,(2)$, terdapat perbedaan pengaruh motivasi tinggi dan motivasi rendah terhadap prestasi belajar dengan $\mathrm{p}(0,042)<0,05$, (3), dan tidak terdapat perbedaan interaksi pengaruh signifikan media pembelajaran dan motivasi belajar terhadap prestasi belajar kompetensi resusitasi pada bayi baru lahir dengan $\mathrm{p}(0,699)>0.05$.

Kesimpulan dalam penelitian ini terdapat perbedaan pengaruh media pembelajaran dan motivasi bejalar terhadap prestasi belajar dan tidak terdapat perbedaan pengaruh signifikan interaksi media pembelajaran dan motivasi belajar terhadap prestasi belajar.
\end{abstract}

Kata kunci :media, motivasi, prestasi belajar

\section{Pendahuluan}

Asfiksia adalah keadaan bayi tidak bernafas secara spontan dan teratur segera setelah lahir. Seringkali bayi yang sebelumnya mengalami gawat janin akan mengalami asfiksia sesudah persalinan. Masalah ini mungkin berkaitan dengan keadaan ibu, tali pusat, atau masalah pada bayi selama atau sesudah persalinan. ${ }^{[3]}$

Data Survei Demografi dan Kesehatan Indonesia (SDKI) tahun 2007 angka kematian bayi sebesar 34 kematian/1000 kelahiran hidup. Angka kematian bayi ini sebanyak $47 \%$ meninggal pada masa neonatal, setiap lima menit terdapat satu neonatus yang meninggal. Adapun penyebab kematian bayi baru lahir di Indonesia, salah satunya asfiksia yaitu sebesar $27 \%$ yang merupakan penyebab ke2 kematian bayi baru lahir setelah Bayi Berat Lahir Rendah (BBLR). ${ }^{[4]}$

Kompetensi dalam mata kuliah asuhan neonatus, balita dan anak pra sekolah harus ditingkatkan karena pelayanan Kebidanan merupakan bagian integral dari pelayanan kesehatan, yang diarahkan untuk mewujudkan kesehatan keluarga.

Rendahnya prestasi belajar mahasiswa dalam kompetensi Neonatus bayi balita dan anak pra sekolah, khususnya kompetensi resusitasi pada bayi baru lahir disebabkan karena tingkat kemampuan berpikir, motivasi belajar, keterampilan melakukan pekerjaan dan perilaku dari masing-masing mahasiswa berbeda-beda. Faktor lain yang menjadi kendala dalam mencapai tujuan pembelajaran adalah metode mengajar dan media yang digunakan dalam menunjang proses pembelajaran. Di Program Studi D III Kebidanan Politeknik Harapan Bersama Tegal saat ini metode pembelajaran praktek untuk mata kuliah Neonatus, bayi, balita dan anak pra sekolah kompetensi resusitasi pada bayi baru lahir cenderung hanya mengggunakan panthom saja, sementara masih banyak media yangt dapat diguanakan untuk pembelajaran yang lebih bervariasi seperti video pembelajaran interaktif. 
Suatu riset baru-baru ini menunjukan bahwa cara paling efektif dalam penggunaan video untuk pembelajaran adalah sebagai peningkatan kualitas pembelajaran. Video sebaiknya digunakan sebagai suatu elemen pembelajaran bersama dengan sumber atau bahan pembelajaran lainnya yang dimiliki.Dalam mengajar suatu topik, penggunaan video didalam kelas harus dipersiapkan dengan baik sebagaimana media pembelajaran atau alat peraga lainya.Tujuan pembelajaran harus ditentukan, begitu juga langkah-langkah pembelajaran serta kegiatan pemantapan harus direncanakan dengan baik. Yang tidak kalah pentingnya adalah semua video yang dipergunakan dalam pembelajaran harus dikaji dulu oleh guru, agar benar benar sesuai dengan kebutuhan pembelajaran. ${ }^{[8]}$

Dalam proses belajar mengajar, motivasi merupakan salah satu faktor yang diduga besar pengaruhnya terhadap hasil belajar. Siswa yang motivasinya tinggi diduga akan memperoleh hasil belajar yang baik. Pentingnya motivasi belajar siswa terbentuk antara lain agar terjadi perubahan belajar ke arah yang lebih positif. Siswa yang termotivasi dengan baik dalam belajar melakukan kegiatan lebih banyak dan lebih cepat, dibandingkan dengan siswa yang kurang termotivasi dalam belajar. Prestasi yang diraih akan lebih baik apabila mempunyai motivasi yang tinggi. ${ }^{[1]}$

Berdasarkan uraian diatas penulis tertarik untuk mengambil judul Pengaruh media pembelajaran dan motivasi belajar terhadap pencapaian prestasi belajar kompetensi resusitasi pada bayi baru lahir.

\section{Metode Penelitian}

Penelitian ini dilaksanakan di Program Studi D III Kebidanan Politeknik Harapan Bersama Tegal. Dalam penelitian ini jenis penelitian yang diguanakan adalah kuantitatif eksperimen dengan menggunakan pendekatan true eksperiment, dalam design ini terdapat dua kelompok yang terdiri dari kelompok eksperimen dan kelompok control.

Populasi dalam penelitian ini adalah mahasiswa Program Studi D III Kebidanan Politeknik Harapan Bersama Tegal Semester III berjumlah 120 mahasiswa, dan sampel penelitian terdiri dari kelompok kontrol yaitu mahasiswa yang mendapatkan pembelajaran dengan media 3 dimensi sebanyak 40 mahasiswa dan kelompok eksperimen yaitu mahasiswa yang mendapatkan pembelajaran dengan VCD interaktif sebanyak 40 mahasiswa.

Variabel dalam penelitian ini yaitu : Variabel dependen prestasi belajar kompetensi resusitasi bayi baru lahir, variabel independen media pembelajaran dan motivasi belajar.

Dalam penelitian ini ada dua instrumen yang digunakan yaitu daftar tilik atau cheklist untuk penilaian prestasi belajar kompetensi resusitasi bayi baru lahir dan kuesioner untuk mengukur motivasi belajar.

Uji validitas dilakukan pada 20 responden diluar sampel, dengan jumlah soal yang akan diujikan yaitu 20 soal. Dimana dari seluruh soal didapatkan $r$ hitung > $r$ tabel $(0,444)$, sehingga seluruh soal dinyatakan valid dan dapat digunakan dalam penelitian ini.

Pada intrumen skala sikap motivasi, reliabilitasnya sebesar 0,859 , dimana $\mathrm{N}=20$ pada tingkat signifikansi 5\% maka rhitung $(0,859)>$ rtabel $(0,444)$, maka item angket pertanyaan angket tersebut reliabel.

Teknik analisis data menggunakan teknik anava 2 jalur dengan uji prasyarat analisis yaitu uji normalitas dengan Kolmogorov-Smirnov dan homogenitas dengan Levene's Test.

\section{Hasil Dan Pembahasan}

Sebelum dilakukan penelitian terlebih dahulu peneliti melakukan uji kesetaraan untuk sampel yang diguanakan dalam penelitian.

Tabel 1. Deskripsi data Indeks Prestasi (IP) Semester 1

\begin{tabular}{lcccc}
\hline \multicolumn{1}{c}{ IP } & A & B & C & Sig. \\
\hline $\mathrm{N}$ & 40 & 40 & 40 & \\
Mean & 3,2 & 3,1 & 3,2 & 0,7 \\
St. Dev. & 0,23 & 0,58 & 0,23 & 38 \\
\hline
\end{tabular}

Berdasarkan tabel 1 diatas maka nilai signifikansi uji kesetaraan T-test untuk data IP (Indeks Prestasi) semester III kelas A, B dan $C$ adalah 0,738.> 0,05 dan nilai rata-rata Indeks Prestasi (IP) Kelas A,B dan C adalah setara. 
Tabel 2. Deskripsi data mahasiswa berdasarkan motivasi belajar

\begin{tabular}{lcccc}
\hline \multirow{3}{*}{$\begin{array}{c}\text { Motivasi } \\
\text { Belajar }\end{array}$} & \multicolumn{2}{c}{ Media 3 dimensi } & \multicolumn{2}{c}{ VCD } \\
& & & \multicolumn{2}{c}{ Interaktif } \\
& F & $\%$ & F & $\%$ \\
\hline Tinggi & 20 & $50 \%$ & 18 & $45 \%$ \\
Rendah & 20 & $50 \%$ & 22 & $55 \%$ \\
Jumlah & 40 & $100 \%$ & 40 & $100 \%$ \\
\hline
\end{tabular}

Dari tabel 2 dapat dilihat bahwa mahasiswa yang mendapatkan pembelajaran dengan media VCD interaktif sejumlah 18 mahasiswa (45\%) memiliki motivasi belajar tinggi dan mahasiswa yang mendapatkan pembelajaran dengan media pembelajaran 3 dimensi sejumlah 20 mahasiswa (50\%) memiliki motivasi belajar tinggi.

Tabel 3. Deskripsi data prestasi belajar

\begin{tabular}{lcccc}
\hline \multirow{2}{*}{$\begin{array}{c}\text { Prestasi } \\
\text { Belajar }\end{array}$} & \multicolumn{2}{c}{ Media Pembebelajaran } \\
& \multicolumn{2}{c}{ Media 3 } & \multicolumn{2}{c}{ VCD } \\
& \multicolumn{2}{c}{ dimensi } & \multicolumn{2}{c}{ Interaktif } \\
\cline { 2 - 5 } & Pre & Post & Pre & Post \\
Lulus & test & test & test & test \\
Tidak Lulus & 16 & 30 & 18 & 34 \\
Jumlah & 24 & 10 & 22 & 6 \\
\hline
\end{tabular}

Dari tabel diatas dapat dilihat bahwa mahasiswa yang mendapat perlakuan dengan media pembelajaran VCD interaktif mendapatkan nilai lulus sejumlah 34 (85\%) mahasiswa atau mengalami kenaikan $40 \%$ dari pretest, sedangkan yang mendapat perlakuan dengan media 3 dimensi yang mandapatkan nilai lulus sejumlah $30(75 \%)$ mahasiswa atau mengalami kenaikan 35\%.

Deskripsi data Prestasi Belajar Kompetensi Resusitasi Bayi Baru Lahirdengan Media VCD Pembelajaran Interaktif seperti teersaji pada tabel 4 berikut:

Tabel 4. Deskripsi data Prestasi Belajar dengan Media VCD Pembelajaran Interaktif

\begin{tabular}{lcc}
\hline & $\begin{array}{c}\text { Skor } \\
\text { Pretest }\end{array}$ & $\begin{array}{c}\text { Skor } \\
\text { Post test }\end{array}$ \\
\hline $\mathrm{N}$ & 40 & 40 \\
Mean & 64.65 & 77.18 \\
Std.Deviation & 12.357 & 8.233 \\
Minimum & 25 & 55 \\
Maximum & 86 & 89 \\
Sum & 2586 & 3087 \\
\hline
\end{tabular}

Dari tabel 4 dapat dilihat bahwa mahasiswa yang menggunakan media pembelajaran VCD interaktif rata-rata terjadi peningkatan sebesar 12,53. Terjadi peningkatan nilai yaitu pada nilai tertinggi pretest yaitu 86 dan nilai tertinggi post tes yaitu 89 .

Deskripsi data Prestasi Belajar Pemasangan AKDR dengan Media Pembelajaran 3 Dimensi.

Tabel 5. Deskripsi data Prestasi Belajar dengan Media Pembelajaran 3 Dimensi

\begin{tabular}{lcc}
\hline & $\begin{array}{c}\text { Skor } \\
\text { Pretest }\end{array}$ & $\begin{array}{c}\text { Skor } \\
\text { Post test }\end{array}$ \\
\hline $\mathrm{N}$ & 40 & 40 \\
Mean & 64.65 & 77.18 \\
Std.Deviation & 12.357 & 8.233 \\
Minimum & 25 & 55 \\
Maximum & 86 & 89 \\
Sum & 2586 & 3087 \\
\hline
\end{tabular}

Dari tabel 5 dapat dilihat bahwa mahasiswa yang menggunakan media pembelajaran 3 dimensi rata-rata terjadi peningkatan sebesar 09,40. Terjadi peningkatan nilai yaitu pada nilai tertinggi pretest yaitu 84 dan nilai tertinggi post tes yaitu 91, sedangkan nilai terendah pretest 36 dan nilai terendah post test 6 .

Tabel 6.Hasil media pembelajaran dan motivasi belajar mahasiswa terhadap prestasi belajar

\begin{tabular}{|c|c|c|c|}
\hline \multirow{2}{*}{$\begin{array}{c}\text { Motivas } \\
\text { i Belajar } \\
\text { (B) }\end{array}$} & \multicolumn{2}{|c|}{ Media Pembelajaran (A) } & \multirow[t]{2}{*}{ TOTAL } \\
\hline & $\begin{array}{l}\text { VCD } \\
\text { Interaktif } \\
(\mathrm{A} 1) \\
\end{array}$ & $\begin{array}{c}\text { Media } 3 \\
\text { dimensi } \\
(\mathrm{A} 2)\end{array}$ & \\
\hline $\begin{array}{l}\text { Motivasi } \\
\text { Tinggi } \\
\text { (B1) }\end{array}$ & $\begin{array}{c}(\mathrm{A} 1 \mathrm{~B} 1) \\
\mathrm{n}=18 \\
\text { mean }=79.44\end{array}$ & $\begin{array}{c}(\mathrm{A} 2 \mathrm{~B} 1) \\
\mathrm{n}=22 \\
\text { mean }=78.14\end{array}$ & $\begin{array}{l}\quad(\mathrm{B} 1) \\
\mathrm{n}=40 \\
\text { mean } \\
78,79\end{array}=$ \\
\hline $\begin{array}{l}\text { Motivasi } \\
\text { Rendah } \\
\text { (B2) }\end{array}$ & $\begin{array}{c}(\mathrm{A} 1 \mathrm{~B} 2) \\
\mathrm{n}=22 \\
\text { mean }=74.05\end{array}$ & $\begin{array}{c}(\mathrm{A} 2 \mathrm{~B} 1) \\
\mathrm{n}=18 \\
\text { mean }=73.50\end{array}$ & $\begin{array}{l}\quad(B 2) \\
n=40 \\
\text { mean } \\
73.77\end{array}=$ \\
\hline TOTAL & $\begin{array}{c}(\mathrm{A} 1) \\
\mathrm{n}=40 \\
\text { mean }=77,18\end{array}$ & $\begin{array}{c}(\mathrm{A} 2) \\
\mathrm{n}=40 \\
\text { mean }=74,93\end{array}$ & \\
\hline
\end{tabular}

Keterangan :

A : Media pembelajaran

B : Motivasi belajar 
A1

:Media pembelajaran VCD interaktif

A2 : Media pembelajaran 3 dimensi

B1 : Motivasi Tinggi

B2 : Motivasi rendah

A1B1 : Kelompok mahasiswa yang memiliki motivasi belajar tinggi

diberi perlakuan dengan media pembelajaran VCD Interaktif

A1B2 : Kelompok mahasiswa yang memiliki motivasi belajar rendah diberi perlakuan dengan media pembelajaran VCD Interaktif

A2B : Kelompok mahasiswa yang memiliki motivasi belajar tinggi diberi perlakuan dengan media pembelajaran media 3 dimensi

A2B2 : Kelompok mahasiswa yang memiliki motivasi belajar rendah diberi perlakuan dengan media pembelajaran media 3 dimensi.

Pada penelitian ini menggunakan tes normalitas dengan menggunakan tes Kolmogorov Smirnov.

Tabel 7. Uji Normalitas

\begin{tabular}{llll}
\hline \multicolumn{4}{c}{ Kolmogorov Smirnov } \\
\hline & $\mathrm{N}$ & Mean & Sig \\
\hline A1B1 & 18 & 79,44 & 0,056 \\
\hline A1B2 & 22 & 74,05 & 0,062 \\
\hline A2B1 & 22 & 78,14 & 0,143 \\
\hline A2B2 & 18 & 73,50 & 0,081 \\
\hline
\end{tabular}

Pada tabel 7 menunjukan nilai $p \geq 0,05$, yang mana pada hasil penilaian ini masingmasing menunjukan angka yang signifikan.

Untuk menguji homogenitas data skor prestasi belajar kompetensi resusitasi bayi baru lahir dengan media pembelajaran 3 dimensi dan VCD Interaktif pada mahasiswa yang mempunyai motivasi tinggi maupun motivasi rendah digunakan uji Levene's Test. Hasil Levene's Test.

Tabel 8. Uji Homogenitas

\begin{tabular}{cccc}
\hline Levene Statistic & df 1 & df2 & Sig \\
\hline 0,927 & 1 & 78 & 0,339 \\
\hline
\end{tabular}

Pada motivasi belajar didapatkan hasil menunjukkan bahwa signifikansi p $(0,339)$ $>0.05$ yang menyatakan varians sama sehingga dapat disimpulkan asumsi homogenitas variansi terpenuhi. Pengujian Hipotesis Penelitian :
Tabel 9. Hasil Uji Analisis Varians 2x2

\begin{tabular}{lcc}
\hline Keterangan & $\mathrm{F}_{\text {hitung }}$ & Sig \\
\hline Media pembelajaran & 6,387 & 0,016 \\
\hline Motivasi & 4,392 & 0,042 \\
\hline $\begin{array}{l}\text { Media } \\
\text { pembelajaran*Motivasi }\end{array}$ & 0,147 & 0,699 \\
\hline
\end{tabular}

Tabel 9 menunjukkan Bahwa terdapat perbedaan pengaruh media pembelajaran 3 dimensi dan media pembelajaran VCD Interaktif terhadap prestasi belajar kompetensi resusitasi pada bayi baru lahir, dimana perhitungan analisis varians dua jalur diperoleh angka signifikans probabilitas (p) media pembelajaran $(0,016)$ $<0.05$. Dengan demikian $\mathrm{H}_{0}$ ditolak dan $\mathrm{H}_{\mathrm{a}}$ diterima.

Terdapat perbedaan pengaruh motivasi belajar tinggi dan motivasi belajar rendah terhadap prestasi belajar kompetensi resusitasi pada bayi baru lahir, dimana perhitungan analisis varians dua jalur diperoleh angka signifikans probabilitas (p) motivasi $(0,042)<0,05$. Dengan demikian $\mathrm{H}_{0}$ ditolak dan $\mathrm{H}_{\mathrm{a}}$ diterima.

Tidak terdapat interaksi pengaruh signifikan antara media pembelajaran dan motivasi belajar terhadap prestasi belajar kompetensi resusitasi pada bayi baru lahir, atau tidak terdapat cukup bukti bahwa salah satu media pembelajaran akan efektif apabila digabungkan dengan kelompok motivasi tertentu, dimana perhitungan analisis varians dua jalur diperoleh $\mathrm{F}_{\text {hitung }}=$ $3.445<\mathrm{F}_{\text {tabel }}(4,0012)$ angka signifikans probabilitas (p) interaksi $(0,699)>0.05$. Dengan demikian $\mathrm{H}_{0}$ diterima dan $\mathrm{H}_{\mathrm{a}}$ ditolak.

Bersadarkan nilai rata-rata, mahasiswa yang menggunakan media pembelajaran VCD interaktif memiliki nilai mean $(77,17)$ > mahasiswa yang menggunakan media pembelajaran 3 dimensi dengan nilai mean (74,93).

Berdasarkan perhitungan analisis varians dua jalur diperoleh $F_{\text {hitung }}=(6,387)$ $>F_{\text {tabel }}(4,0012)$,angka signifikans probabilitas (p) media pembelajaran $(0,014)<0.05$. Hal ini menunjukkan bahwa terdapat perbedaan pengaruh media pembelajaran 3 dimensi dan media pembelajaran VCD Interaktif terhadap 
prestasi belajar kompetensi resusitasi pada bayi baru lahir, dimana mahasiswa yang mendapatkan pembelajaran dengan media pembelajaran VCD interaktif hasilnya lebih baik dari mahasiswa yang mendapatkan pembelajaran dengan media 3 dimensi.

Kenyataan saat ini dengan banyaknya jumlah anak yang masuk sekolah, maka memerlukan alat-alat yang membantu lancarnya belajar anak dalam jumlah yang besar pula. Media pendidikan ini misalnya seperti buku-buku di perpustakaan, laboratorium atau media lainnya yang dapat mendukung tercapainya prestasi belajar dengan baik. ${ }^{[7]}$

Media mempunyai pengaruh yang signifikan terhadap prestasi belajar asuhan inisiasi menyusu dini, dimana media VCD terbukti memberikan pengaruh yang lebih baik dari pada media panthom. ${ }^{[2]}$

Penggunaan media pembelajaran yang berbeda dapat memperhatikan prestasi belajar yang berbeda sehingga dapat dibandingkan penggunaan media pembelajaran mana yang menghasilkan prestasi belajar yang baik. Penggunaan media pembelajaran akan membantu siswa dalam mencapai tujuan yang telah direncanakan dan membantu dosen dalam menyampaikan materi kompetensi resusitasi pada bayi baru lahir, sehingga penggunaan media pembelajaran dapat meningkatkan prestasi belajar mahasiswa dalam mencapai suatu kompetensi tertentu. ${ }^{6}$

Berdasarkan perhitungan analisis varians dua jalur diperoleh $\mathrm{F}_{\text {hitung }}=4,392>$ $F_{\text {tabel }} \quad(4,0012)$, angka signifikans probabilitas (p) motivasi $(0,042)<0,05$. Hal ini berarti terdapat perbedaan pengaruh motivasi belajar tinggi dan motivasi belajar rendah terhadap prestasi belajar kompetensi resusitasi pada bayi baru lahir.

Signifikans antara mahasiswa yang memiliki motivasi tinggi diberi media pembelajaran apapun (baik media VCD interaktif maupun media 3 dimensi) tetap akan menunjukkan prestasi belajar yang lebih baik dari pada mahasiswa yang memiliki motivasi rendah.

Motivasi belajar adalah daya penggerak dari dalam diri individuuntuk melakukan kegiatan belajar untuk menambah pengetahuan dan keterampilan serta pengalaman. ${ }^{[10]}$

Motivasi ini tumbuh karena ada keinginan untuk bisa mengetahui dan memahami sesuatu dan mendorong serta mengarahkan minat belajar siswa sehingga sungguh-sungguh untuk belajar dan termotivasi untuk mencapai prestasi. ${ }^{[10]}$

Berdasarkan perhitungan analisis varians dua jalur diperoleh $\mathrm{F}_{\text {hitung }}=3.445<$ $\mathrm{F}_{\text {tabel }} \quad(4,0012) \quad$ angka signifikans probabilitas (p) interaksi $(0,699)>0.05$. Dengan demikian $\mathrm{H}_{0}$ diterima dan $\mathrm{Ha}$ ditolak.

Berdasarkan hasil uji hipotesis dapat dikatakan bahwa, tidak terdapat pengaruh signifikan interaksi media pembelajaran dan motivasi belajar terhadap prestasi belajar kompetensi resusitasi pada bayi baru lahir, atau tidak terdapat cukup bukti bahwa salah satu media pembelajaran akan efektif apabila digabungkan dengan kelompok motivasi tertentu.

Pengaruh Media VCD Interaktif dan Media Gambar Terhadap Prestasi Belajar Mata Pelajaran Ilmu Pengetahuan Sosial Ditinjau dari Motivasi Belajar Siswa Kelas IV Sekolah Dasar Negeri 02 Cakranegara Nusa Tenggara Barat, didapatkan hasil terdapat interaksi pengaruh pembelajaran bermedia VCD, gambar dan motivasi belajar terhadap prestasi belajar siswa $(\mathrm{F}$ hitung $<\mathrm{F}$ tabel atau 0,943 $<6,63$ pada taraf signifikansi $5 \%){ }^{5}$

\section{Kesimpulan}

Adanya perbedaan pengaruh pembelajaran dengan media VCD Interaktif dengan media 3 dimensi terhadap prestasi belajar kompetensi resusitasi pada bayi baru lahir.

Adanya perbedaan pengaruh motivasi belajar yang tinggi dan motivasi belajar yang rendah terhadap hasil belajar kompetensi resusitasi pada bayi baru lahir.

Tidak adanya pengaruh interaksi media pembelajaran dan motivasi belajar terhadap prestasi belajar kompetensi resusitasi pada bayi baru lahir. Interaksi antara media pembelajaran dan motivasi belajar tidak berpengaruh signifikan terhadap prestasi belajar mahasiswa atau tidak terdapat cukup bukti bahwa salah satu 
media pembelajaran akan efektif jika digabungkan dengan motivasi tertentu.

\section{Daftar Pustaka}

[1] Slameto, 2003. Belajar dan FaktorFaktor yang

MempengaruhinyaRineka

Cipta,Jakarta.

[2] Kristuningtyas,W, 2007. Pengaruh Media Pembelajaran VCD dan Panthom Terhadap Prestasi Belajar Inisiasi menyusu Dini ditinjau dari minat belajar mahasiswa di Akademi Kebidanan Giri Satria Husada Wonogiri, Tesis,Program Pascasarjana Universitas Sebelas Maret Surakarta.

[3] Depkes RI, 2008. Millenium Development Goals 2015. Jakarta.

[4] Depkes RI, 2009. Sistem Kesehatan Nasional. Jakarta.

[5] Astini, 2010. Pengaruh Media VCD Interaktif dan Media Gambar Terhadap Prestasi Belajar Mata Pelajaran Ilmu Pengetahuan Sosial Ditinjau dari Motivasi Belajar Siswa Kelas IV Sekolah Dasar Negeri 02 Cakranegara Nusa Tenggara Barat, Tesis, Universitas Sebelas Maret.Surakarta.

[6] Daryanto,2010, Media Pembelajaran Peranannya Sangat Penting Dalam mencapai Tujuan Pembelajaran. Gava Media, Yogyakarta.

[7] Suradi, 2011, Pengaruh media pembelajaran dan motivasi belajar terhadap hasil belajar IPA Mata Pelajaran IPA tentang konsep dasar Ekologi di SMP 4 Bojong Pekalongan,Tesis,Universitas Sebelas Maret, Surakarta.

[8] Prawira, Atmaja. 2012, Psikologi Pendidikan Dalam Perspektif Baru.Ar-Ruzz Media.Yogyakarta.

[9] Hariyanto.,2012, Cara Meningaktakan Prestasi Belajar Anak. Website http://belajarpsikologi.com Diakses pada tanggal 4 Februari 2016.
[10] Iskandar. 2012, Psikologi Pendidikan Sebuah Orientasi Baru, Jakarta. 